introducing them into a hydrogen flame, was due to the rapid disintegration of the metal. I have ascertained the cause of disintegration of the metal. this phenomenon, and ho have produced a metal in a state produces it, and in and which is absolutely stable at a temperature where nearly all substances melt or are consumed; a metal which, although originally soft and pliable, becomes as homowhich, although ord as rigid as steel. When wound in the form geneous as glass and as rigid as steel. When at the most dazzling incandescence as when cold, and cannat be annealed by any process now commonly known, for the cause of this shrinking process now cracking of the wire is due entirely to the expansion of the air in the mechanical and physical pores of the platinum, and the contraction upon the escape of the air. Platinum as sold in commerce may be compared to sandstone, in which the whole is made of a great number of particles with many air spaces. The sandstone upon melting becomes homogeneous and no air spaces exist.

With platinum or any metal the air spaces may be eliminated and the metal made homogeneous by a very simple process. This process I will now describe. I had made a large number of platinum spirals, all of the same size and from the same quality of wire ; each spiral presented to the air a radiating sirface of three-sixteenths of an inch ; five of these were brought by the electric current up to the melting-point, the light was measured by a photometer, and the average light was equal to four standard candles for each spiral just at the melting-point. One of the same kind of spirals was placed in the receiver of an air-pump, and the air exhausted to 2 millimetres; a weak current was then passed through the wire, to slightly warm it for the purpose of assisting the passage of the air from the pores of the metal into the vacuum. The temperature of the wire was gradually angmented, at intervals of ten minutes, until it became red. The object of slowly increasing the temperature was to allow the air to pass out gradually and not explosively. Afterward the current was increased at intervals of fifteen minutes. Before each increase in the current the wire was allowed to cool, and the contraction and expansion at these high temperatures caused the wire to weld together at the points previously containing air. In one hour and forty minutes this spiral had reached such a temperature without melting that it was giving a light of twentyfive standard candles, whereas it would undoubtedly have melted before it gave a light of five candles had it not been put through the above process. Several more spirals were afterwards tried, with the same result. One spiral, which had been brought to these high temperatures more slowly, gave a light equal to thirty siandard candles. In the open air this spiral gave nearly the same light, although it required more current to keep it at the same temperature. Upon examination of these spirals, which had passed through the vacuum process, by the aid of a microsrove no cracks were visible; the wire had become as white as siver, and had a polish which could not be given it by any other means. The wire had a less diameter than before treatment, and it was exceedingly difficult to melt in the oxy-hydrogen flame. As compared with untreated platinum, it was found that it was as hard as the steel wire used in pianos, and that it could not be anciealed at any temperature.

My experiments with many metals treated by this process b-ve proved to my satisfaction, and I have no hesitation in stating that what is known as annealing of metals to make them soft and pliable is nothing more than the cracking of the metal. In every case where a hard drawn wire had been annealed a powerful microscope revealed myriads of cracks in the metal. Since the experiments of which I have just spoken I have, by the aid of Sprengel mercury pumps, produced higher exhaustion, and have, by consuming five hours in excluding the air from the wire and intermitting the current a great number of times, succeeded in obtaining a light of eight standard candles from a spiral of wire with a total radiating surface of I-32nd of an inch, or a surface ¿bout equal to one grain of buckwheat. With spirals of this small size which have not passed through the process, the average amount of light given out before melting is less than one standard candle. Thus I am enabled, by the increased capacity of platinum, to withstand high temperatures, to employ small radiating surfaces, and and thus reduce the energy required for candle light. I can now obtain eight separate jets, each giving out an absolutely steady light, and each equal to sixteen standard candles, or a total of I 28 candles, by the expenditure of 30,000 foot-pounds of energy, or less than one horse-power. As a matter of curiosity I have made spirals of other metals, and excluded the air from them in the manner stated. Common iron wire may be made to give a light greater than platinum not heated. The iron becomes as hard as steel, and just as elastic. Nickel is far more refractory than iron. Steel wire used in pianos becomes decarbonised, but remains hard, and becomes the colour of silver. Aluminium melts only at a whit $\epsilon$-heat.

In conclusion, it may be interesting to state that the meltingpoints of many oxides is dependent on the manner of applying the heat ; for instance, pure oxide of zirconium does not fuse in the flame of the oxy-hydrogen blow-pipe, while it melts like wax and conducts electricity when on an incandescent platinum spiral which is at a far lower temperature; on the other hand oxide of aluminum easily melts in the oxy.hydrogen flame, while it only vitrifies on the platinum spiral.

\section{THE INAUGURATION OF ARAGO'S STATUE}

THE statue to Arago recently unveiled at Perpignan is not the first erected to that great astronomer and greater physicist. In $1867 \mathrm{M}$. Isaac Pereire, then representative of the native place of Arago in the Imperial Chamber of Deputies, erected one at his own expense at Estagel. The inauguration was accompanied by speeches delivered by the generous donor, M. Bertrand, the perpetual secretary of the Academy of Science, and others. It was stated then that Arago had supported against his own party the construction of the railways by public companies, and had been grossly abused by some of his political friends. Although a political leader, it must be said, to the glory of Arago, that he never was influenced by party considerations. $\mathrm{He}$ was always writing, and speaking, and voting according to the dictamina of his own judgment. These facts should be remembered, as efforts have been made in the recent Arago celebration, to degrade him into a mere politician, which never was the case. Arago was made a member of the Provisiona? Government of France in February, 1848; it was owing to his personal exertion that the abolition decree was proclaimed before the convocation of the National Assembly. It is true that he was appointed in the beginning of May one of the quinquemuirs of the Executive Commission. But this Government was overthrown by the popular rising of the end of June, and frors: that time he abstained from taking any prominent part is politics.

Arago was not rich, his works having been inostiy published in the Annuaire du Bureau des Longitudes without any copyright, and sold for the benefit of the Bureau, of which he was the mosit influential member. His paying works were all of them posthumous, and edited by $M$. Barras, the Perpetual Secretary of the Agricultural Society of France. The sale was not so large as anticipated, and the publisher who purchased the copyright from the inheritors failed. The sale of the Annuaire was so large during Arago's lifetime, that the Burean had a profit by it. Since his death it has become necessary to provide special functs for the publication of that useful work.

Arago had no salary at all as director of the Observatory. I?e was appointed every year by the Bureau, receiving only 200 . for his membership. His other salaries were $50 l$. as a member of the Academy of Sciences, 250 . as Perpetual Secretary, and when he was lecturing on astronomy $50 \%$. The functions of deputy and member of Municipal Council of Paris being entirely gratuitous, he was no receiver of any other public moneys. Under the Republic his membership of the Assembly brought him $\mathrm{I} l$. a day.

From the eloquent eloge pronounced by M. Paul Bert at the recent inauguration, we take the following extract :-

"To contemplate Arago under all the aspects that may attract the admiration of posterity we must think of him as a man of science overturning the Newtonian hypothesis of the emission of Iight, determining the physical constitution of the sun, explaining the scintillation of the stars, the nature of the aurora borealis, discovering magnetisation by currents, the origin of the electric telegraph, extending to all bodies magnetic properties; finally, for I must limit myself to the most prominent points, indicating to the most eminent of his disciples the star still unknown and invisible, whose discovery introduced order among the perturbed planets, and which still remains the most extraordinary mark of the power of human genius. As a professor, again, before three thousand auditors at the Observatory, or in his chair as Perpetual Secretary writing his incomparable scientific notices, or dictating, when blind, his popular astronomy, always, by speech or by pen, marvellous for his clearncse, his 
accuracy, his power and fulness, elevating all he touched, returning to the astonished inventor his discovery developed and fertilised, sowing broadcast his ideas, and rejoicing when others, friends or foes, were enriched by the precious fruits of his genius. As a scientific historian he excelled Condercet, equalled Cuvier and Fontenelle, and was characterised above all others by his eagerness to give every one his due, and his jealous love of justice. As an orator he carried into the tribune the vigour and clearness of the scientific chair, vivified by the emotions of master-spirits, and dominating the assembly by his lofty stature, with his beautiful Southern head, and his eye full of fire. He was a man, in fact, in whom the will to act was united with the consciousness of power, an intelligence marvellously comprehensive and powerfully creative, so bold and yet so prudent at times that it never commited an error that required to be retracted. Of an ardent but loyal nature, ready for power, but incapable of liatred, and thirsting for justice, a heart sensitive and valiant, sometimes drawn, says a contemporary, to show itself severe to the strong in order to support the weak; a soul austere but a brow serene; a father and citizen worthy of the ancient legends, and able, like Carnot on quitting life to bear the noble witness: - 'My hands are clean and my heart pure.' From the extent of the sketch your may judge what will be the nature of the picture."

\section{PALAEZOIC ROCKS IN SOUTH-EAST OF ENGLAND}

IN a communication to the Geological Section of the meeting of the Britisle Association at Plymouth in 1878 , I called attention to the significance of the result of the deep boring at Messrs. Meux's ; as to the upper Devonian beds there met with next beneath the cretaceous strata; also as to the importance of some further knowledge as to the direction of the dip of the said upper Devonian beds. An accurate acquaintance with this point is essentially needed with reference to its immediate bearing on a question which may possibly become one of national import. ance, namely, the place of the true coal measure series beneath our south-eastern area, and which must serve as an excuse for another short communication on the same subject.

The question involved has attracted the attention of sundry foreign geologists during the past year, and upon our own area facts have been ascertained which now enable us to arrive inferentially at what, but a year since, was mere speculation.

M. Dewalque, at a recent meeting of the Belgian Geological Society, remarked first on the absence of Jurassic and Triassic deposits, as along the palæozoic ridge extending from the Ardennes by the north of France, being just what the borings at St. Trond, Laecken, Menin, and Ostende would indicate. Secondly, that inasmuch as the palæozoic formations of Belgium and the north-west of France are extended into England, it is an important point, with reference to the prolongation of the Belgian coal-basin, that London should be known to be situated imme. diately over a formation, which is itself so close to the coal measures. "The supposition that the dip of these upper Devonian beds is to the south, and that they belong to the extension of our northern basin is that which is the most probable. The coal formation may therefore occur at a short distance south of London, and at a workable depth.

"With a southern dip it may be that these beds (upper Devonian) belong to the extension of our southern basin. In this case coal may occur in the north as well as in the south, and nearer on this side (north) than on the south. Should there be such a coal basin, it might be as useless as ours (Belgium) of the Condros and the Entre Sambre and Meuse." The exact significance of this latter alternative of the Belgian geologist may not, perhaps, be understood by English geologists generally, as it has reference to a feature in the physical structure of Belgium, but the which is very properly referred to by $M$. Dewalque, now that the palzozoic band of the Continent is known to reach our south east district. The band of Belgian and North of France coal. measures may be truly represented as trough-shaped, however produced.

M. Dewalque adds: "Starting from the supposition that our (Belgian) old strata are prolonged westward into England, and from the fact that upper Devonian strata occur under London, we are led to admit that the band of Silurian slates of the

"Further Evidence on the Range of the Palæozoic Rocks beneath the South-East of England," by R. A. C. Godwin-Austen, F,R.S. Paper read at the Sheffield meeting of the British Association.
Ostende boring must pass north of London. These slates muse be separated from the upper Devonian by other beds, such as the black slates of the Menin Shaft, which are Silurian. Considering the geographical position of these three places, together with the east and west direction of our older formations, it would not seem that their prolongation into England would carry them sufficiently north of London, so that the Devonian beds there should represent our Condros basin, and not that of Namur. If, then, at that place (London) we are in a prolongation of the Namur basin, the strata at Meux's must dip south; consequently it is most probable that the coal-measures are to be found at a short distance south."

Such were the inferences drawn by M. Dewalque in $187 \mathrm{~S}$ from the results of the boring at Messrs. Meux's.

The supposition that the Silurian strata met with at Ostende would in their course westwards run north of London have been proved by the occurrence of beds of Wenlock age at Ware, near Hertford, twenty miles north of London. This discovery has come most opportunely to supply the information which only a year since was needed, as to the dip of the upper Devonian strata at Messrs. Meux's brewery. The succession of the palæozoic strata in this the English side of the channel, even into the far west, is just what it is in Belgium and the north of France, from Brussels and Ostende from north to sonth. There the successive members of the series mostly rise to the surface and are exposed in all the valley of denudation extending north from the line of the coal measures, as long since laid down by Dumont.

With this guidance, and in spite of the little as yet known with respect to our own underground structure on the sonth-east, it can be safely put in relation with what obtains on the European continent for an extent of 400 miles; the order in which the successive members of the palrozoic series rise to the surface from beneath one another there, may be taken as our guide on to the order and relation of the upper Devonian at the end of Tottenham Court Road near Oxford Street, and the section at Ware.

The question of the strike and direction of the dip of the beds at Messrs. Meux's is now determined as forming part of the northern band of the trough containing first, the mountain limestone series, and, next above, the true coal measures.

For practical guidance one point alone remains to be considered : from the place of the Upper Devonian strata in the heart of London, what must be allowed for the breadth of the outcrop of mountain limestone series next in sequence? In parts of Belgium the mountain limestone has been estimated at 600 feet thick; it is less than that in an east and west direction. The nearest place to London at which this is exposed is in the north of the Boulonnais denudation; where, with its associated beds, it may be put at 400 feet. The breadth of such a mass at its outcrop, and with an angle of $30^{\circ}$ to $35^{\circ}$, such as the Devonian bed at Menx's had, would be nearly doubled, or about 800 feet; in other words the lower members of the coal measure foimation may be fairly expected to occur at about that distance south from a corner of Tottenham Court Road and Oxford Street. The upper, or productive coal-measures, still further to the south.

What has been ascertained beyond all doubt as to the line of section underlying a part of our English area from London to Ware, may safely be taken as holding good for a great extent of country on the east as in the west. The ages of more modern overlying formations do not affect this question, as is shown by the borings now in England, but more abundantly in the Euro. pean continent. In our attempts to trace accurately hidden physical arrangements of the earth's crust, the restrictions to be observed are-the positive data of the ascertained thickness of the several formations and their several positions, and which enable us to replace, without much chance of error, the line of each band and of its angle of dip.

\section{UNIVERSITY AND EDUCATIONAL \\ INTELLIGENCE}

UNIVERSITY COLLEGE, BRISTOL, will shortly commence its fourth Session. The calendar, which is before us, states that there were 448 students in the college in the second session; and in the third, 576 , of whom 355 were men and 221 women; 172 came in the day-time and 404 in the evening. Good progress is being made by the Engineering Department, which is designed to afford a thorough scientific education for students intending to become mechanical or civil engineers, surveyors, or architects. The course for engineering is such that students can pursue it during the six winter months of each year, and the council of the 